\title{
Validity after Limited Scale Trial in Designing Indonesian Language Learning Multimedia for Class V Elementary School Students
}

\author{
Hasnul Fikri' ${ }^{1}$, Ade Sri Madona ${ }^{2}$, and Yetti Morelent ${ }^{1}$ \\ ${ }^{1}$ Pendidikan Bahasa Indonesia, FKIP,Universitas Bung Hatta, Padang \\ ${ }^{2}$ Pendidikan Guru Sekolah Dasar, FKIP,Universitas Bung Hatta, Padang
}

Corresponding Author:

Hasnul Fikri

hasnul.fikri@bunghatta.ac.id

Received: 18 January 2019

Accepted: 24 March 2019

Published: 31 March 2019

Publishing services provided by

Knowledge E

(c) Hasnul Fikri et al. This article

is distributed under the terms of

the Creative Commons

Attribution License, which

permits unrestricted use and

redistribution provided that the

original author and source are

credited.

Selection and Peer-review unde the responsibility of the ICEST 2018 Conference Committee.

\section{Abstract}

This article aims to explain the revision and validation of instructional media designed in order to generate an interactive multimedia-based Indonesian language learning media that contain character education for grade $V$ elementary school students in order to implementation of Curriculum 2013. This research is a development research with a 4-D model consisting of four steps that is define, design, development, and dissemination. This article is written based on the development stage. The data collection is done by recording the process and the result of the revision and the validation questionnaire. For process data and revision result used content analysis technique while for expert validation used simple statistic. Based on the research found the following things. First, the product is revised based on respondents' input on the validity, practicality, and effectiveness tests and analysis of the Curriculum 2013. Improvements are made to the theme so that it complies with the Curriculum 2013 revised 2017. In addition, the media display is also improved so it is simpler but functional. Secondly, based on the validation of the revision product, it is known that this interactive multimedia-based learning media are validly seen from two aspects, namely the language aspect and the display aspect. On the aspect of the display obtained a score of 4.50 while the language aspect obtained a score of 4.33 , so the average of both aspects is 4.42 (categorized valid). From both of these considerations, it was concluded that well designed mediums were used in learning activities that they were feasible to be tested on a large scale.

Keywords: Format, Microsoft Word Template, Style, Insert, Template learning media, interactive multimedia, character value, development research.

\section{Introduction}

This research is motivated by the awareness of the importance of language function in human life, including in education. With language, one can convey ideas, thoughts, 
feelings or information to others, both orally and in writing (Iskandarwassid and Dadang, 2008: 226).

Mastery of language skills can be done through language learning, in addition through language acquisition. In the practice of language learning, teachers often encounter various obstacles, including students are not eager or not interested in following the lesson. Among the factors causing this unfavorable condition are (1) the learning activity of the language still tends to be done classically and learning is more emphasized on reading and listening activities, (2) the teacher still often focuses on the use of textbooks, (3) teachers tend to use less media, if using media it was first generation media such as drawings and reading materials, and (4) teachers less accentuate the benefits of language skills for their students, whether for learning activities or for their daily lives, now and in the future (Fikri \& Madona, 2017).

Seeing such conditions, it is necessary to provide alternative learning oriented on how students learn to find by himself the information presented as best as possible so that learners can understand all the study materials contained in learning Indonesian language easy and enjoyable. This has become a demand in process standards of Curriculum 2013. Improvements are made to all learning components such as learning objectives, lesson materials, instructional media, learning strategies, and learning evaluations (Rusman, Kurniawan, \& Riyana, 2012).

One alternative is the use of interactive multimedia learning media. This media combines the use of images, sound, animation, and video simultaneously, in accordance with the needs in learning Indonesian. In addition, students get immediate feedback because at the end of language learning, questions are provided relating to the text they have learned. The truths of answers and grades that students get on objective questions will appear automatically after they enter the answers and ask to be assessed. Thus, students immediately know the number of correct and wrong answers from the learning that he has done. Into the media is also inserted with the character value, which is adapted to the text used. This character value will be asked for students to answer it after reads a single text. In addition, the media used by teachers in the classroom can also be used again by students at home, either using a computer (PC), laptop or android device (Fikri \& Madona, 2017).This paper is prepared based on the implementation of the research conducted in 2017, namely the revision phase of the product based on a small-scale test. This article aims to describe the revision and validation of instructional media designed in order to produce an interactive multimedia-based Indonesian language learning media that is character education for Grade $\mathrm{V}$ students in order to implementation of Curriculum 2013. 


\section{Literature Review}

The use of interactive multimedia is very potential to overcome the problems in learning Indonesian as described in the Introduction section. Novana et al. (2012) explains that interactive multimedia provide an easy way to visualize large objects and not easy in the procurement. Wawan \& Bambang (2012) stated that in order to realize more innovative and interactive learning, teachers are required to be innovative in finding breakthrough learning ability to combine text, image, audio, music, animated picture or video in one mutually supportive unit to achieve the goal learning. Ramansyah (2014) also stated that in order to achieve the ideal conditions in learning Indonesian, it is necessary to develop interactive multimedia-based media that can provide clear information for students.

The development of interactive multimedia is based on the perception that learning activities will be good, effective, and fun if supported by instructional media that can attract the interest and attention of children and can be operated by the students themselves. The learning method by using computer or smartphone device tend to be more favored by children.

Indonesian-based interactive multimedia learning media using android can be an effective breakthrough to overcome the relationship problems between Teachers and Students in managing information in learning. An interesting and interactive course of study materials can encourage students' learning motivation, so that students can master learning and can learn wherever they are. Related to this, Yuliana, et.al. (2017) states that multimedia is an integration of several different types of media and technology to improve the learning process

To produce quality multimedia, Newby, et al. (2000) says that multimedia development should consider three things: (1) methods, i.e. techniques and procedures used in learning (cooperation, gaming, presentation, or discussion); (2) media, i.e. media used in learning to attract students (video, text, images, and animation); and (3) materials, i.e. learning content which includes: motivation, orientation, information, application, and evaluation.

\section{Research Method}

Based on the background and purpose of this study, the type of research that will be conducted is Research and Development (R \& D) is research that oriented to develop products (Borg \& Gall, 1983). Research and development is a process used to develop and validate the products used in education and learning. This research includes research 
that develops and produces new products in a learning system that will be applied to learners as users.

In accordance with the development model used, there are four main stages in the process of producing a reliable product, namely define, design, develop, and disseminate. This article is generated from the development stage, especially a revision based on the results of small-scale trials that have been done in the first year of research (Fikri and Madona, 2017). Based on input from validators and respondents in a limited-scale trial, it is identified with what needs to be improved before media products are tested on a wide scale. In addition, the revisions are also made based on the revision of the Curriculum 2013.

The validity of the product is done by an expert, consisting of two aspects, namely the appearance and language of the media. Because the material presented in this medium is material that fits the theme in the student book based on the Revised Curriculum 2013, then the media content does not need validation by the expert.

The subject to revised product validation are two validators consisting of (1) experts in the field of Indonesian language education for primary schools and (2) experts in the field of information technology and communication. To collect data from research subjects, the instrument used is a validation questionairre. In addition, feedback on product improvements is recorded and grouped according to linguistic and display aspects.

A data analysis technique used in this study is content analysis, namely grouping and explaining the improvement records of the research subjects. To analyze the validity of the product, qualitative data are converted to quantitative data. Based on this quantitative data is calculated the average score of each validator and the average score of both validators. The formula used is:

$$
R=\frac{\sum_{j=1}^{n} V i j}{n m}
$$

Whereas:

$$
\begin{aligned}
& R=\text { average of assessment result from expert / practitioner } \\
& V i j=\text { score of assessment results of experts / practitioners to } j \mathrm{j} \text { criteria } i \\
& n=\text { number of experts assessing } \\
& m=\text { number of criteria }
\end{aligned}
$$

Learning devices are said to be valid if the average obtained reaches 3.00 or more. Determination of the prevalence rate and media is obtained by criteria such as Table 1.

\section{Results and Discussion}


TABLE 1: Criteria for Determination of the Validity.

\begin{tabular}{lc|} 
Range & Category \\
\hline $1.00-1.99$ & Not Valid \\
$2.00-2.99$ & Less Valid \\
$3.00-3.99$ & Valid Enough \\
$4.00-4.59$ & Valid \\
$4.60-5.00$ & Very Valid \\
\hline & (Widjajanti, 2008)
\end{tabular}

\subsection{Results}

\subsubsection{Revision of learning media}

Based on the discussion and suggestions from the validator, interactive multimedia for Indonesian language is then revised. Revisions are made twice, especially those relating to the content and appearance of developed media with regard to suggestions or considerations given by the validator though validation sheet and discussion.

Comparisons between suggestions or considerations by validators and revisions that have been made can be seen in Table 2 .

TABLE 2: Comparisons between Suggestion or Consideration by the validator and Revision.

No.

1.

2.

3.

4.

6.

necessary to correct the ambiguous sentences in the text.

7.

It is necessary to adjust the selection of character values with the characteristics of the students.

8. Simplify the used of sentences in the character value section.

\section{Revision}

The cover design has been adapted to the theme.

The color resolution is further enhanced and clarified.

The background has been adjusted color with the appearance of the material.

Text writing has been adapted to the Indonesian Spelling.

The sentence in writing the character value has been corrected in accordance with the comment of the validator.

Ambiguous texts in the story text have been corrected.

The selection of character values has been adjusted to the characteristics of students.

The use of sentences in the character value section has been simplified according to the comment validator. 
Based on the Peraturan Menteri Pendidikan dan Kebudayaan Nomor. 21 of 2016 about Standar Isi Kurikulum 2013, it was made changes to the theme of learning. The comparison theme between before and after revision can be seen in Table 3.

TABLE 3: Comparison of Theme Between Before and After Revision.

\begin{tabular}{|c|c|c|c|c|}
\hline \multirow[t]{2}{*}{ Semester } & \multicolumn{4}{|c|}{ Theme } \\
\hline & Theme & Before Revision & Theme & After Revision \\
\hline \multirow[t]{5}{*}{ I } & 1 & $\begin{array}{l}\text { Benda-benda di Lingkungan } \\
\text { Sekitar }\end{array}$ & 1 & $\begin{array}{l}\text { Organ Gerak Hewan dan } \\
\text { Manusia }\end{array}$ \\
\hline & 2 & Peristiwa dalam Kehidupan & 2 & Udara Bersih bagi Kesehatan \\
\hline & 3 & $\begin{array}{l}\text { Kerukunan dalam } \\
\text { Bermasyarakat }\end{array}$ & 3 & Makanan Sehat \\
\hline & 4 & Sehat Itu Penting & 4 & Sehat Itu Penting \\
\hline & 5 & $\begin{array}{l}\text { Bangga sebagai Bangsa } \\
\text { Indonesia }\end{array}$ & 5 & Ekosistem \\
\hline \multirow[t]{4}{*}{ II } & 6 & Organ Tubuh Manusia & 6 & Panas dan Perpindahannya \\
\hline & 7 & Sejarah Peradaban Indonesia & 7 & Peristiwa dalam Kehidupan \\
\hline & 8 & Ekosistem & 8 & Lingkungan Sahabat Kita \\
\hline & 9 & Lingkungan Sahabat Kita & 9 & Benda-benda di Sekitar Kita \\
\hline
\end{tabular}

From Table 3, there is a significant difference between the learning themes in the 5th grade of elementary school between before and after the revision. In this 2 nd year, based on the revision of the 2013 curriculum, there are three themes that are replaced namely the Kerukunan dalam Bermasyarakatreplaced with Udara Bersih bagi Kesehatan, Bangga sebagai Bangsa Indonesia is changed into Makanan Sehatand Sejarah Peradaban Indonesiareplaced with Panas dan Perpindahannya. As a result, reforms were carried out on all three themes. In addition, although other themes do not change, but there is a change in the existing material on the theme. This should also be accommodated in the revision.

The results of the implementation of this instructional media design resulted in interactive multimedia application interface display. Details can be seen in the following description. First, the opening page view (media cover) which has a single button, the entry button. The entry button is useful for entering into the application and leading to the main menu. There is no display change on the cover, and is completely described as in the following view: 


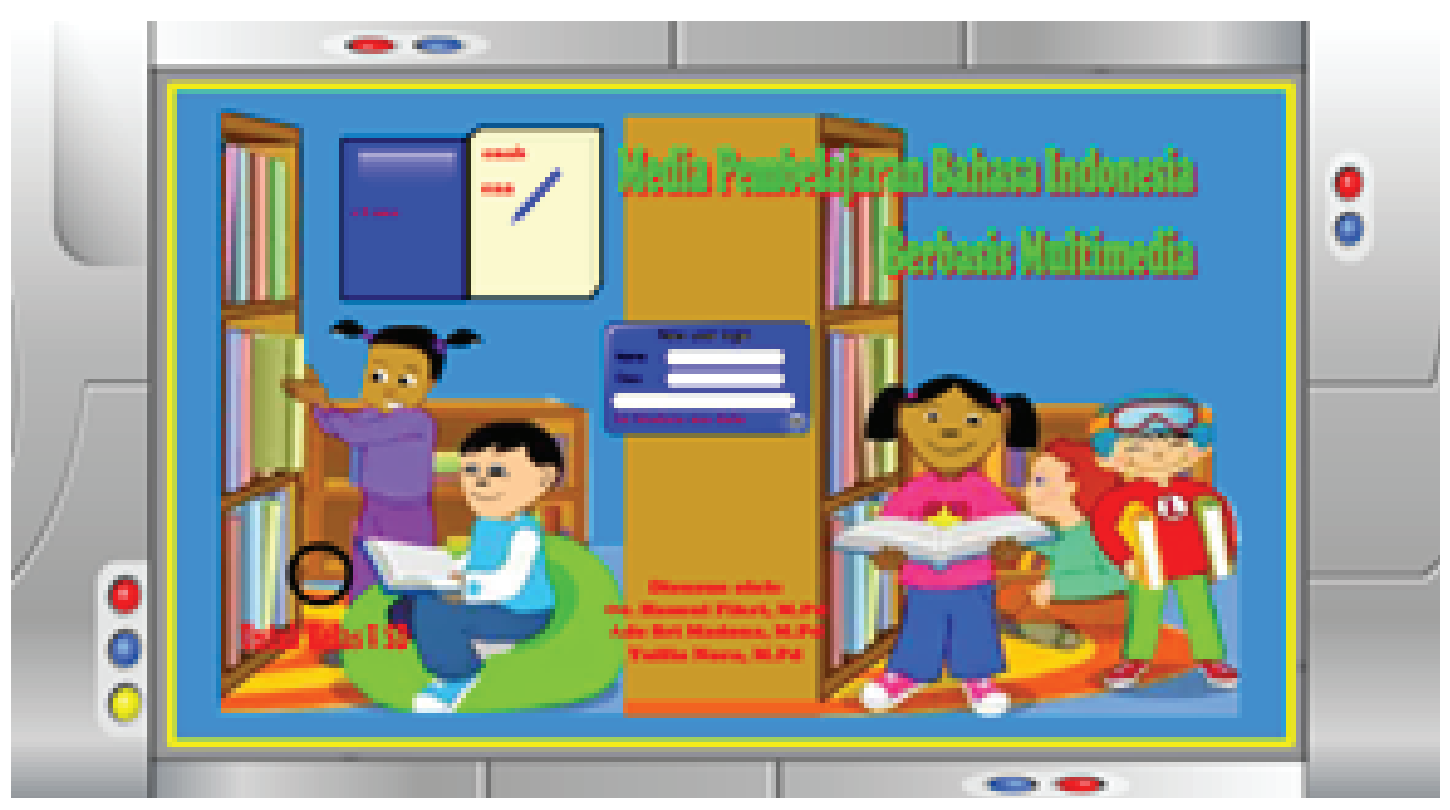

Second, the main menu display consists of a cover button, instructions, materials, exercises, biodata, and exit buttons like in the following view:

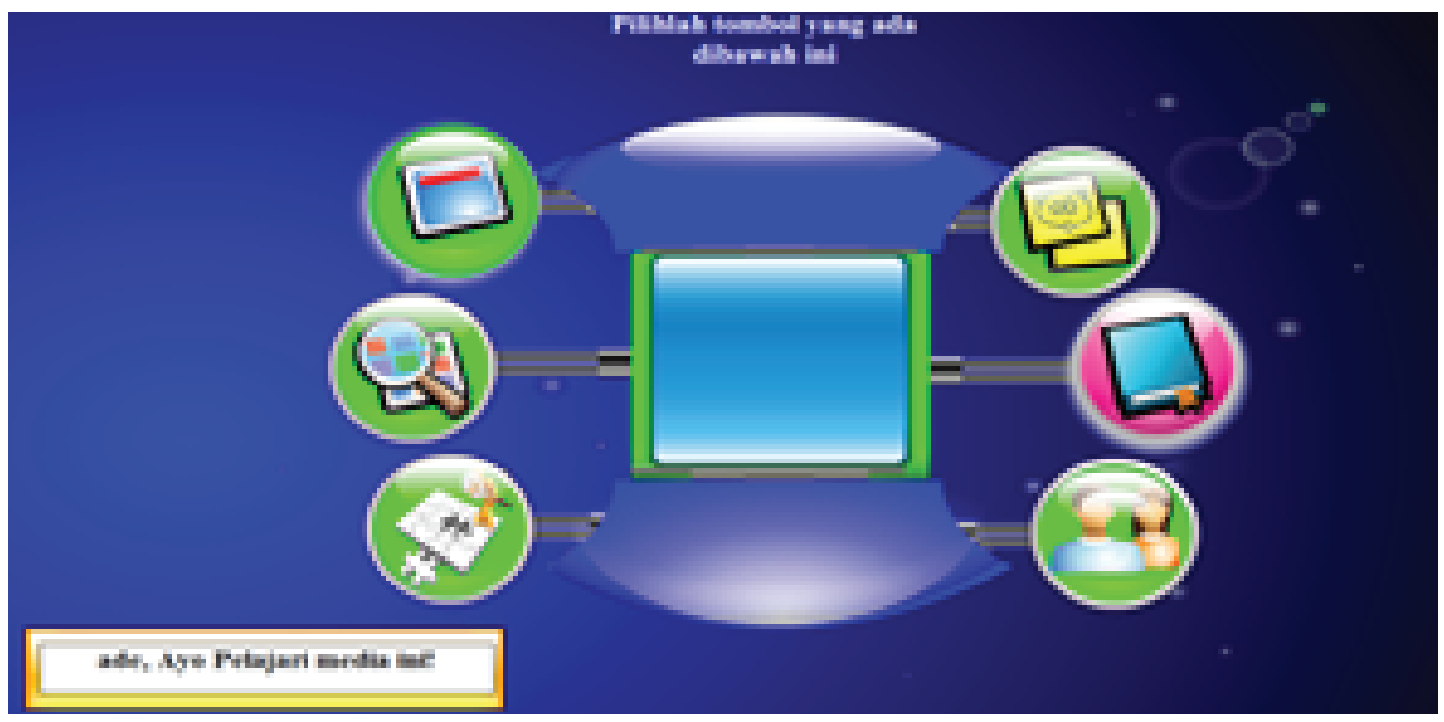

Third, the menu display of the learning theme that contains the overall material map before and after the revision can be seen in the following views:

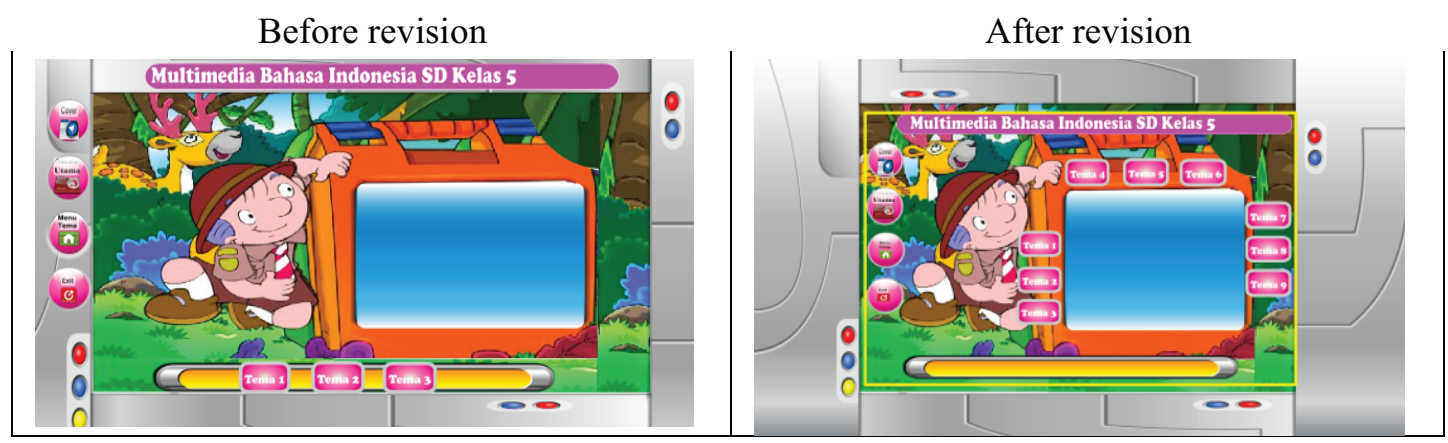


Fourth, the menu display option subtema consisting of 3 subtema and each subtema consists of 6 meetings. No revisions are made to this section, as in the following view:

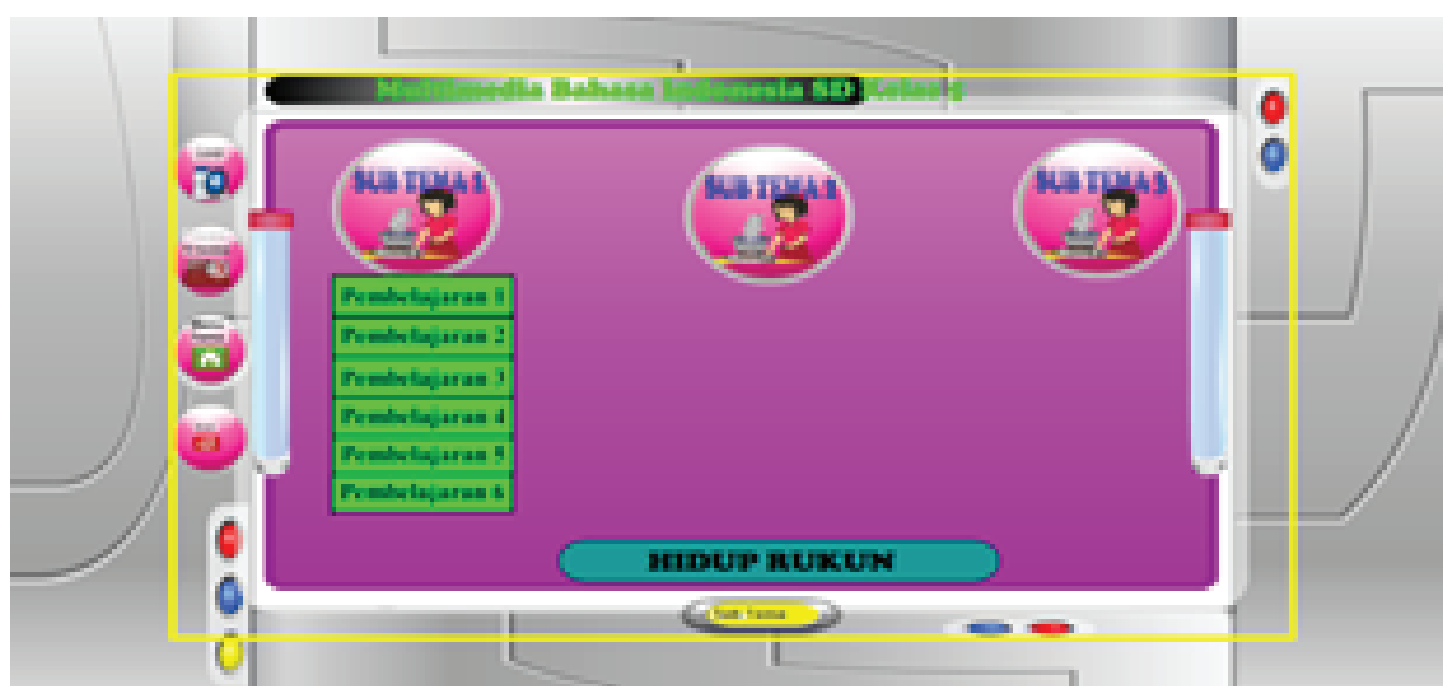

Fifth, the display of material in the form of images and text. The available text contains important information regarding the character values contained in the text provided. From the text that has been read, students are asked to find the value of characters contained in the text. At the end of the course the student will be directed to the quiz by answering the question to look for the character value contained in the text. The character value contained in the text that is the value of the spirit of nationality and love of the country. In the student worksheet view, there is a revision in the display that was originally a blank worksheet and after revision the worksheet appearance was replaced by matching the answer. In detail, can be seen in the pictures below: 

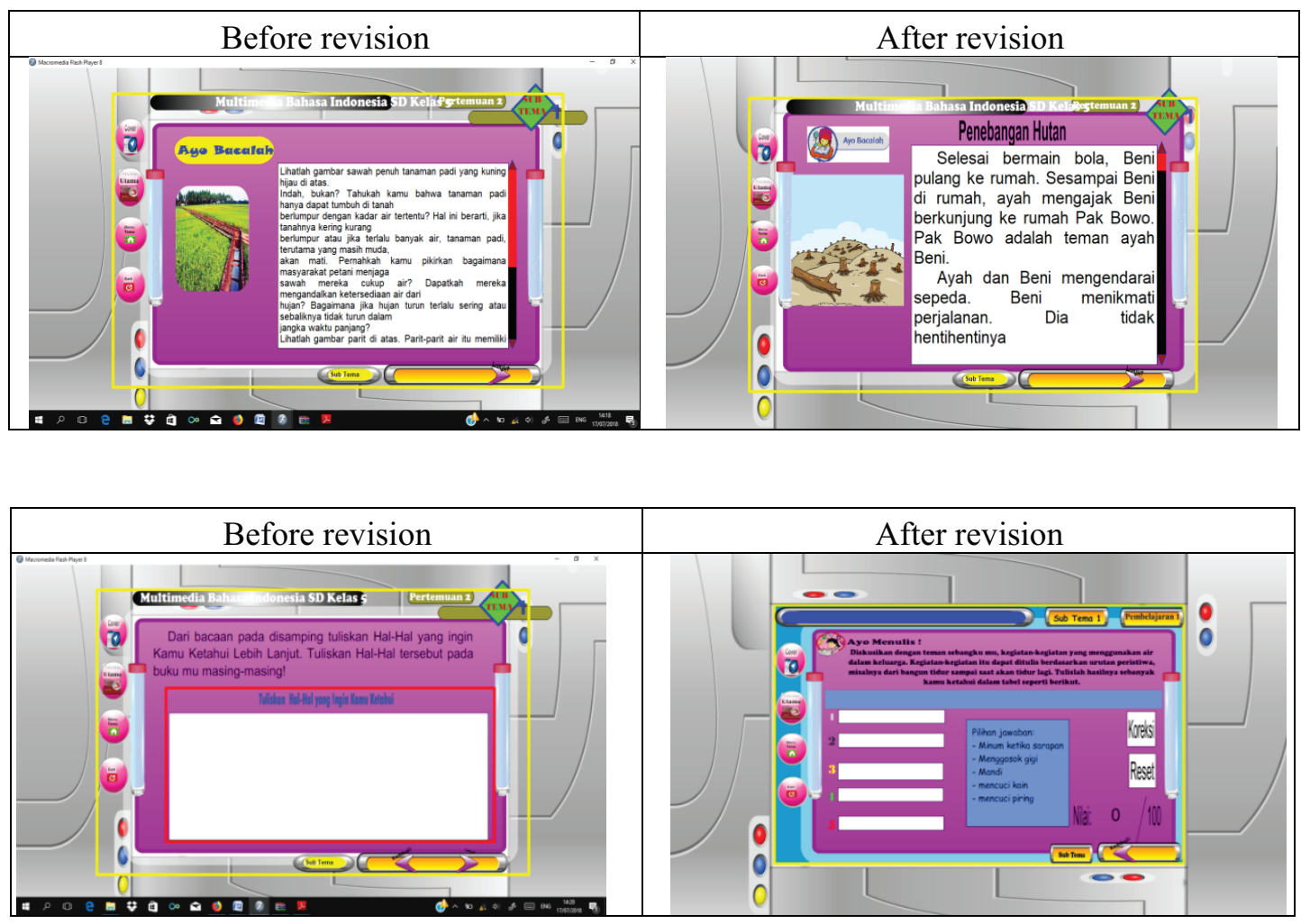

Sixth, the appearance of the material in the form of pictures. Students are asked to pay attention to the image on the display. From the picture students are asked to look for important information contained in the picture, and at the end of the student's material was led to find the character value contained in the picture, among which the value of environmental care, tolerance, and social care characters. At the revision stage changes are done by creating pictures with text, when the product is run the initial appearance of the picture only and when the cursor is directed to the image then it appears the writing replace the image. The media form is illustrated in the following views:

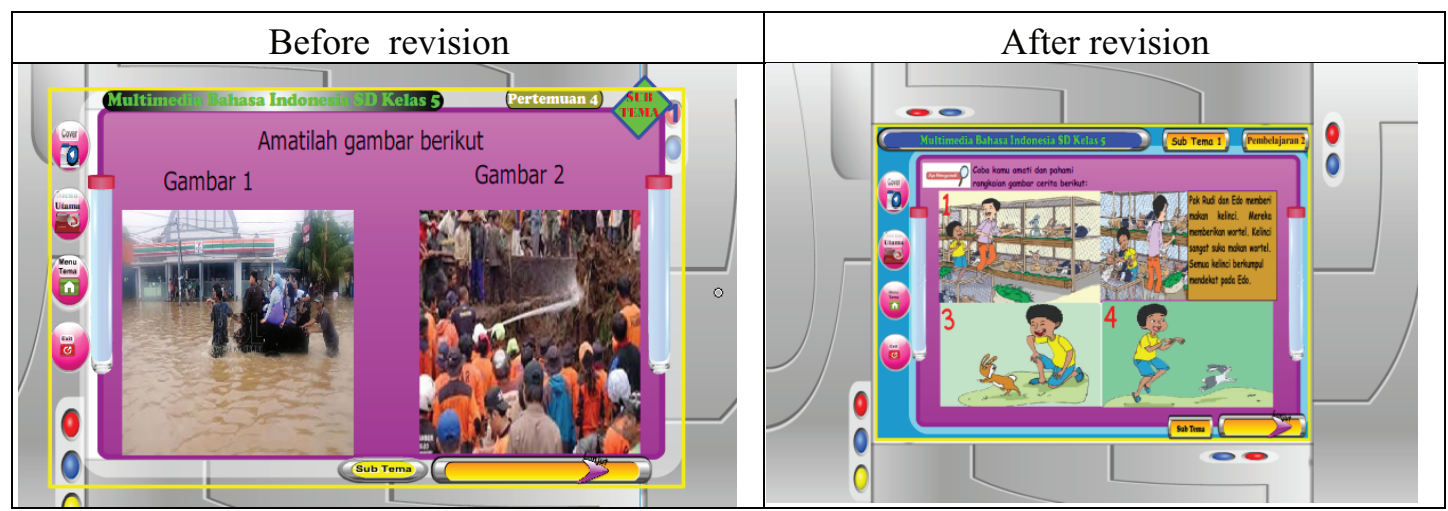

Seventh, the character charge display is revised by improving the display image, originally written in English and then replaced with character education. This difference can be seen in the following figures: 


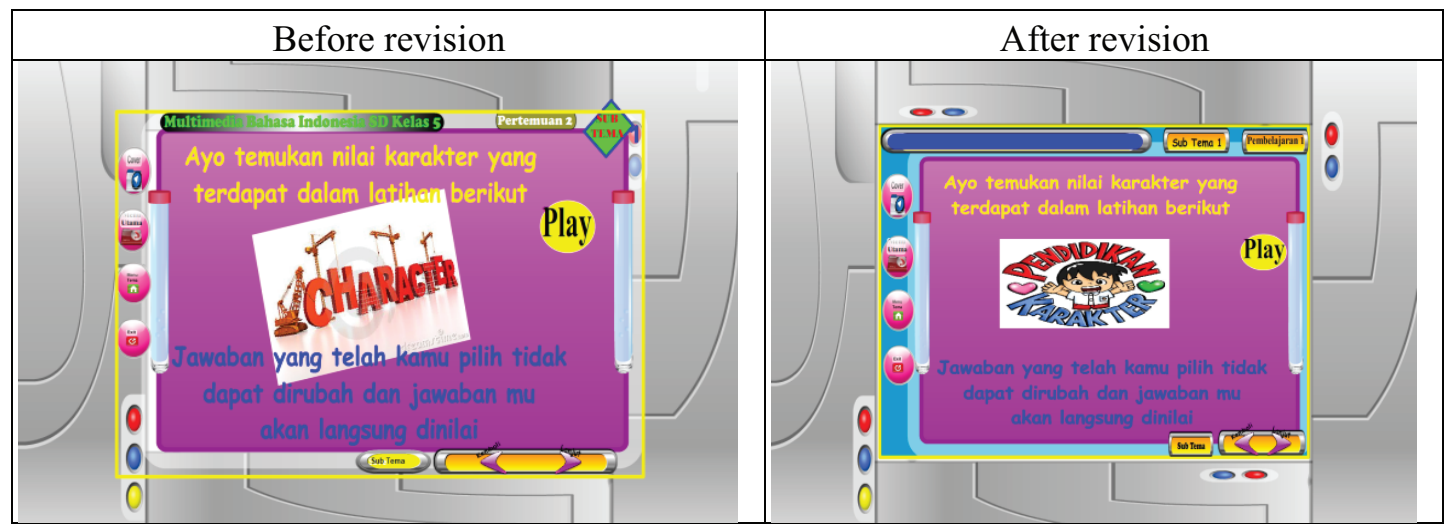

\subsubsection{Validasi}

Validation of Indonesian media based on interactive multimedia is done by two experts, namely one Computer Lecturer at Program Studi Pendidikan Teknik Informatika dan Komputer and one lecturer of Indonesian Language Education at Program Studi Pendidikan Guru Sekolah Dasar. Aspects observed are aspects of appearance and language aspects. The validation results on the display aspect are presented in Table 4.

TABLE 4: Validation of Indonesian Learning Media Based on Multimedia Interactive on Display Aspect.

\begin{tabular}{l|l} 
No. & Indicator That are Rated \\
a & Interactive multimedia view \\
b & Clarity of instructions for program usage \\
c & Image display quality \\
d & The use of animated images is interesting \\
e & Color composition \\
f & Conformity between text and animation \\
\hline g & The font type and size are appropriate. \\
h & Spatial setting / layout.
\end{tabular}

\begin{tabular}{|c|c|}
\hline Scores & Category \\
\hline 5 & Very Valid \\
\hline 4 & Valid \\
\hline 4 & Valid \\
\hline 5 & Very Valid \\
\hline 4 & Very Valid \\
\hline 5 & Valid enough \\
\hline 5 & Valid \\
\hline 4 & Very Valid \\
\hline 4.50 & Valid \\
\hline
\end{tabular}

Based on Table 4 it can be seen that the validation of Indonesian media based on interactive multimedia assessed by validator in general is 4.5 with valid category. Seeing the exposure of the above assessment, it is found that the teaching materials of Indonesian media based on interactive multimedia have been valid from the display so that it can be used as a guide for the implementation of the learning process.

Another aspect that is seen is the language aspect. Here is the validation of Indonesian multimedia based on interactive multimedia for language aspect as shown in Table 5. 
TABLE 5: Validation of Indonesian Learning Media Based on Multimedia Interactive on Language Aspect.

No. Indicator that are Rated
a. The truth of grammar
b. Using good and correct Indonesian rules
c. Using Indonesian spelling
d. The language used is simple, straightforward, easy to
e. The simplicity of sentence structure
f. Guidance clarity and direction.

Average

\begin{tabular}{|c|}
\hline Scores \\
\hline 4 \\
\hline 4 \\
\hline 4 \\
\hline 4 \\
\hline 4 \\
\hline 5 \\
\hline 4.33 \\
\hline
\end{tabular}

\begin{tabular}{|c|}
\hline Category \\
\hline Valid \\
\hline Valid \\
\hline Valid \\
\hline Valid \\
\hline Valid \\
\hline Very Valid \\
Valid
\end{tabular}

Based on Table 4 it is known that the validation of Indonesian media based on interactive multimedia assessed by validator in general is 4.33 with valid category. Seeing the exposure of the above assessment, obtained the belief that teaching materials presented in the medium of learning based on interactive multimedia language has been validly used in terms of language as a medium of learning in the implementation of the learning process.

Tables 3 and 4 have shown average scores on display and language aspects. If these two aspects are combined, the average score for both aspects is 4.42 . This can be seen in Table 5.

TABLE 6: Recapitulation of Average Score of Both Aspects.

\begin{tabular}{|l|l|c|c|}
\hline No. & Aspects that are Rated & Scores Average & Category \\
\hline 1 & Display Aspect & 4.50 & Valid \\
\hline 2 & Language Aspect & 4.33 & Valid \\
\hline Average of both aspects & 4.42 & Valid \\
\hline
\end{tabular}

Based on Table 5, it is known that the validation of Indonesian media based on interactive multimedia is assessed by two validators with an average score of 4.42 with valid category. It can be concluded that the learning media of Indonesia based on interactive multimedia are feasible to be used as a supporter of independent learning

\section{Discussion}

Media that has been designed and tested is then revised. The revision was done on the guided aspect, which was originally still in English and then changed in Indonesian, 
character education values are quite complicated adapted to the level of student development, the text examples adapted to the condition of the pupil. With such revisions, the validity and validity of the designed media will increase.

In addition, the theme and content of teaching materials have been adapted to the revised 2013 curriculum and endorsed by the Peraturan Menteri Pendidikan dan Kebudayaan Nomor. 21 of 2016 about Standar Isi Kurikulum 2013. Thus, it is believed that in terms of content (content validity), the material contained in this designed medium is valid.

Validity is required to test a study. The word "valid" is often interpreted correctly, correctly, validly, legitimately; so the word validity can be interpreted with accuracy, truth, sincerity or validity (Sugiyono, 2011). Research products that have been developed are said to be valid if they meet certain criteria. According to Plomp (2010) the characteristics of the product are said to be valid if the product can reflect the soul of knowledge (state of the art knowledge).

The overall validity of Indonesian media based on interactive multimedia can be seen in table 5. The result in table 5 it shows that the average validation test of Indonesian media based on interactive multimedia as a whole is 4.15 with valid category. So, it can be concluded that the media device of interactive multimedia Indonesia can be used in presenting the material to students of grade $V \mathrm{SD}$.

In the implementation of the research many obstacles that cause inhibition of the implementation process of research include: (1) in the process of making multimudia takes a long time in data collection and manufacture of Indonesian media based on interactive multimedia, (2) between student's book and teacher's book are not appropriate because there is an imbalance between teacher's book and student's book, (4) there is often a system error in multimedia application (macromedia flash 8), so that the work of media often repeated, (5) it is not easy to determining Indonesian material because in the material of Bahasa Indonesia in the Curriculum 2013 has been integrated with other learning, (6) in making of media also faced obstacle in adjusting the color, appearance and material so often pictures, colors, and materials are exchanged.All of these problems can be eliminated through repeated attempts. Thus, it is necessary to endeavor to produce a valid medium. 


\section{Conclude}

The Indonesian-based interactive and character-based multimedia learning media has been revised based on input from validators on a limited scala trial and analysis of curriculum changes 2013 . The revisions were made to linguistic, character values, appearance, and themes and learning materials.

Based on the validity test through two experts, each in the field of compoter technology and Indonesian language obtained the result that interactive multimedia in Class V Primary School is in the category very valid. This can be seen from the average score for both aspects of 4.42 (categorized as valid).

\section{Acknowledgement}

Acknowledgment to the Directorate General of Higher Education (Dirjen Dikti) who has funded this research. Acknowledgments to the Rector of Universitas Bung Hatta and Chairman of LPPM Bung Hatta University who have facilitated this research.

\section{References}

[1] Borg.Walter R. \& Gall, Meredith D. (1983). Educational Research an Instructional. Fourth Edition. New Cork: Logran Inc.

[2] Fikri, Hasnul \& Ade Sri Madona. (2017). Pengembangan Multimedia Pembelajaran Bahasa Indonesia Bernilai Pendidikan Karakter untuk Siswa Kelas V SD. Puitika, 13 (2), 111-141.

[3] Iskandarwassid dan Dadang Sunendar. (2008). Strategi Pembelajaran Bahasa. Bandung: Rosda.

[4] Muliyardi. (2006). "Pengembangan Model Pembelajaran Matematika Menggunakan Komik di Kelas I Sekolah Dasar". Disertasi tidak diterbitkan. Surabaya: Universitas Negeri Surabaya.

[5] Newby, T. J., Donald, S., James, L., James, D., Russell, \& Anne, T. L. (2000). Instructional Technology for Teaching and Learning. New Jersey: Prentice-Hall Inc.

[6] Novana, T., Budi, A.P., \& Sukaesih, S. (2012). Pengembangan Multimedia Interaktif Berbahasa Inggris Materi Vertebrata sebagai Suplemen Pembelajaran Di SMA. Unnes Journal of Biology Education, (Online), 1 (1): 95-99, (https://journal.unnes.ac.id/sju/index.php/ujbe/article/view/381), diakses 2 Juli 2018. 
[7] Plomp, T. (2010). An Introduction to Educational Design Research. Netherlands: SLO Netherlands Institute for Curriculum Development.

[8] Ramansyah, W. (2014). Pengembangan Multimedia Pembelajaran Interaktif Berbasis Adobe FlashCS3 pada Kelas 1 SDN Bancaran 3 Bangkalan. Edutic-Scientific Journal of InformaticsEducation, 1(1), 1-11.

[9] Rusman, Kurniawan, D., \& Riyana, C. (2012). Pembelajaran Berbasis Teknologi Informasi dan Komunikasi: Mengembangkan Profesionalitas Guru. Jakarta: Raja Grafindo Persada.

[10] Sugiyono. (2011). Metode Penelitian Kuantitatif Kualitatif dan R\&D. Bandung: Alfabeta

[11] Wawan, S., \& Bambang, EP. (2012). Pengembangan Multimedia Pembelajaran Interaktif untuk Mata Kuliah Organisasi Komputer. Journal Speed - Sentra Penelitian Engineering dan Edukasi V 4 (2):61, http://ejurnal.net/portal/index.php/speed/article/ view/838, diakses 5 Juli 2018.

[12] Widjajanti, E. (2008). Pelatihan Penyusunan LKS Mata Pelajaran Kimia Berdasarkan KTSP Bagi Guru SMK/MAK. Makalah Disajikan dalam Kegiatan Pengabdian Pada Masyarakat. Jurusan Pendidikan Kimia FMIPA Universitas Negeri Yogyakarta.

[13] Yuliana, Siswandari, \&Sudiyanto. (2017). The Development of Accounting Digital Comic Media In the Material of Writing Bank Reconciliation Report For Students of Vocational Secondary School. Jurnal Pendidikan dan Kebudayaan. 2 (2), 135-146. 